\title{
Marie-Anne Coebergh-van der Marck
}

\author{
In de ban van het incestverbod: \\ Analyse van een historische omslag in de verbeelding \\ van erotiek tussen broer en zuster. \\ Hilversum: Uitgeverij Verloren 2012 \\ 153 pp. ISBN 978-90-8704-335-4
}

In de ban van het incestverbod: Analyse van een historische omslag in de verbeelding van erotiek tussen broer en zuster is het proefschrift verdedigd door Marie-Anne Coebergh-van der Marck aan de Universiteit Leiden. Het boek omvat een analyse van verschillende culturele manifestaties van het incestverbod en beschouwingen over incest tussen broer en zuster besproken aan de hand van drie boeken: Mijn zuster de negerin van Cola Debrot (1934), Mijn satijnen hart van Remco Campert (2006), Ultramarijn (2005) van Henk van Woerden, en de film Grimm van Alex van Warmerdam (2003). De werken dienen als illustratie voor een veranderende houding tegenover incest bekeken in een historisch perspectief. Het uitgangspunt vormt de veronderstelling dat incest door de eeuwen heen als schending van een taboe en een wet werd beschouwd. De auteur wijst op de aanwezigheid van het incestmotief in de antieke oudheid en haalt Ovidius' Metamorphosen aan als bewijs voor een lange literaire traditie van dit motief. Verder merkt ze op dat de negatieve houding tegenover incest geleidelijk is veranderd:

Kort en goed, in (met name) de tweede helft van de vorige eeuw en in het domein van de verbeelding lijkt het verbod op incest tussen broer en zuster een zodanige transformatie te hebben ondergaan dat de transcendente dimensie en het bijbehorende vermogen tot fixatie van talige, culturele en maatschappelijke structuren op losse schroeven zijn komen te staan. (Coebergh-van der Marck 2012: 12)

De auteur kondigt aan dat het haar bedoeling is om deze veranderende houding tegenover het incestverbod in kaart te brengen en dat haar boek "een zoektocht naar het hoe en waarom van een historische en fundamentele omslag" (pg. 12) zal vormen. Dit verschijnsel wordt besproken aan de hand van geselecteerde Nederlandstalige werken die vóór (in dit geval in 1934) en na de bovengenoemde omslag (dus ruim na de tweede helft van 
de $20^{\text {ste }}$ eeuw - hier: na het jaar 2000) zijn gepubliceerd. In de inleiding presenteert de auteur het plan van haar werk: na een bespreking van de drie boeken en de film onderzoekt ze de onderlinge verschillen en plaatst deze in een "contemporaine maatschappelijke en culturele context" (pg. 15). De verschillen in de behandeling van het incestthema in de gekozen werken worden met behulp van drie vragen onderzocht:

1. Is erotiek tussen broer en zuster, schending van de orde, eigenlijk wel zo erg?

2. Is de traditionele, in het incestverbod verankerde ordening ook automatisch de enig denkbare ordening?

3. Als traditionele, in het incestverbod verankerde en op een transcendente dimensie gebaseerde structuren hun draagvlak verliezen, welk alternatief dient zich dan aan? (Coebergh-van der Marck 2012: 14)

Volgens de auteur zijn de teksten die aan die analyse onderworpen worden representatief voor de "recente en minder recente verbeelding van heersende denkpatronen" (pg. 12). De auteur deelt mee dat ze een "interdisciplinair georiënteerde, culturele analyse" (pg. 12) als haar onderzoeksmethode heeft gekozen. Het probleem van incest wordt dus vanuit verschillende kanten belicht: in Mijn zuster de negerin wordt het in verband met rassenvermenging geplaatst; in Het satijnen hart fungeert incest als element in de discussie over kunst en leven; in Ultramarijn en Grimm speelt het een rol in de context van ontheemding, een zoektocht naar een eigen plek en de eigen/vreemd tegenstelling. In deze contexten wordt het verschijnsel van incest geïnterpreteerd als teken van een "ongeneeslijk heimwee naar een verloren oereenheid" (pg. 14). Vanuit het methodologische perspectief maakt het boek voornamelijk gebruik van psychoanalytische en poststructuralistische theorieën.

Het boek heeft een overzichtelijke structuur en bestaat uit een inleiding, waar de bovengenoemde probleemstelling en aanpak worden vermeld, en zes hoofdstukken. Hoofdstuk 1 is bedoeld als presentatie van de theoretische achtergrond voor de interpretatie van de gekozen werken die in de volgende vier hoofdstukken plaatsvindt. Hoofdstuk 6 vormt een recapitulatie en er worden conclusies getrokken. Verder volgt een samenvatting in het Nederlands en Engels, en een bibliografieopgave.

In de inleiding wordt het probleem van de erotische liefde tussen zus en broer als een oeroud fenomeen beschouwd dat zich al in Ovidius' Metamorphosen voordoet. Naast vragen naar de oorsprong van het motief van incest in de literatuur, worden ook de voornaamste werken uit wereldliteraturen (Engelse, Duitse, Franse en Nederlandse) vermeld waar dit motief opduikt. De auteur merkt op dat in de $17^{\text {de }}$ eeuw een literaire trend begint waar incest een dodelijke afloop heeft. Hoewel dit vanaf John Ford en zijn 'T is Pity She's a Whore (1633) tot Hugo Claus met De Metsiers (1950) en Een bruid in de morgen (1953) het geval is, blijkt dat in de $20^{\text {ste }}$ eeuw incest niet per se een tragisch vervolg moet hebben, zoals in Nabokovs Ada or Ardor: A Family Chronicle (1969).

In hoofdstuk 1 presenteert Coebergh-van der Marck de problematiek van incest en het incestverbod in een breed kader, waar zowel cultuur (gepresenteerd aan de hand van filosofische stromingen en wetgeving) als natuur (onderzoek naar biologische oorzaken en implicaties) in acht worden genomen. Er wordt ook verwezen naar de verschillen in de wettelijke status van incest in diverse landen (in sommige is het een strafbare 
overtreding, in andere alleen een vorm van maatschappelijk niet toegestaan gedrag). Naast psychoanalytische (de auteur beroept zich op Jung, Freud, Lacan, Kristeva en Žižek) en structuralistische (Lévi-Strauss en Derrida) theoretische overwegingen worden er ook wetenschappelijke bevindingen op het gebied van de recente evolutionaire biologie en gedragswetenschap aangehaald. Terwijl Freud en Lévi-Strauss het incestverbod als sleutel tot cultuur beschouwen, beweren sommige wetenschappers (Edward Westermarck, Arthur Wolf, Patrick Bateson) dat incest tegen natuurlijke selectie in gaat en dat mensen die vanaf hun jeugd samen opgroeien, in werkelijkheid voor elkaar niet seksueel aantrekkelijk zijn. De theoretische achtergrond wordt heel breed geschetst met behulp van uitvoerige citaten en passages waar afzonderlijke theoretische aspecten (bijvoorbeeld mechanismes van verdichting en verschuiving, functie van dromen, spiegelstadium etc.) worden uitgelegd. Dit hoofdstuk vormt een sterk punt van het proefschrift, want de ingewikkelde en meervoudige natuur en implicaties van het thema worden er duidelijk gesignaleerd. Daarnaast stelt de auteur de vraag of het incestueus verlangen werkelijk bestaat: is incest een vorm van lust of is het een fantasme dat zich in de wereld van verbeelding afspeelt?

In hoofdstuk 2 wordt Mijn zuster de negerin (1934) van Cola Debrot besproken. Debrots novelle over de terugkeer van een jongeman na zijn jarenlange verblijf in Europa naar een "Nederlands-West-Indisch eiland" wordt vanuit een psychoanalytisch perspectief benaderd. Slechts een paar keer wordt er naar postkoloniale kritiek verwezen: de auteur beroept zich op het concept van het "koloniale verlangen" (pg. 35; pg. 48) en Bhabha's werken (pg. 38; pg. 39). De focus ligt op het concept van unhomeliness en associaties met het Freudiaanse Unheimliche, zodat dit hoofdstuk een bijna uitsluitend psychoanalytische interpretatie omvat. Helaas blijkt dit soort analyse - hoewel zeer grondig en gedetailleerd uitgevoerd - niet overtuigend voor het lezen van postkoloniale literatuur. Verder lijken sommige opmerkingen niet volledig doeltreffend te zijn, zoals bijvoorbeeld de interpretatie van de passage over de terugkeer van Frits Ruprecht naar het huis Miraflores. De scène waar Frits voor de ouderlijke slaapkamer staat, interpreteert de auteur in de Freudiaanse traditie waar de kinderlijke angsten voor "waargenomen of gefantaseerde ouderlijke coïtus" centraal staan en vervolgens refereert ze aan de "casestudy de Wolvenman" (pg. 38). Zo ontstaat er de indruk dat de auteur de psychoanalytische aanpak in de oorspronkelijke, letterlijke vorm toepast, zodat de personages als echte mensen aan psychoanalyse worden onderworpen.

De auteur focust zich in dit hoofdstuk vooral op de verlangens van het hoofdpersonage. Koloniale relaties, beschouwingen over de ander en maatschappelijke processen vormen alleen maar een terloops geschetste achtergrond. Bij de bespreking van machtsverhoudingen in de koloniale, maatschappelijke en erotische context ontbreekt er een theoretische basis, zoals bijvoorbeeld de voor de hand liggende verwijzing naar Michel Foucaults begrip van discours. De koloniale en seksuele verhoudingen in Debrots boek zouden beter toegelicht kunnen worden.

In hoofdstuk 3, dat een discussie over Het satijnen hart omvat, staat de verhouding van kunst en leven centraal. Coebergh-van der Marck concentreert zich op de "instabiele identiteit" van het hoofdpersonage van het boek; de oude schilder, Van Otterlo. Omdat 
de seniele schilder in een wereld leeft waar zijn dromen, herinneringen en werkelijkheid met elkaar vervlochten zijn, beslist de auteur dat ook dit boek voor een psychoanalytische bespreking geschikt is. Aan bod komen dus overwegingen over de rol van het onbewuste en het bewuste, de imaginaire orde, dromen en mechanismes van verschuiving en verdichting die parallel staan voor talige mechanismes van metonymie en metafoor (pg. 52-59). Coebergh-van der Marck wijst op dromen en het onbewuste als principes van het surrealisme, waardoor de verbinding tussen kunst en het leven van de schilder wordt geaccentueerd. Haar uitleg over de mechanismes van dromen is zo uitgebreid dat ze op meerdere plekken van het hoofdthema van het proefschrift - incest in teksten van cultuur - afwijkt. Incest komt overigens enkel in hoofdstuk 14 van Het satijnen hart aan bod, en de scène van een korte vereniging tussen halfbroer en halfzuster die in dit hoofdstuk plaatsvindt, wordt door Coebergh-van der Marck omschreven als "metafoor van het herstel van een verloren oereenheid" (pg. 65).

Hoofdstuk 4 handelt over Ultramarijn van Henk van Woerden. Er is sprake van twee incestueuze verhoudingen tussen drie personages. In het eerste geval gaat het over de relatie tussen het veertienjarige meisje Aysel en haar halfbroer Joakim, in het tweede tussen de dochter van Aysel, Ôzlem, en Joakim, haar vader. De plot van het verhaal doet denken aan het verhaal van Oedipus en de interpretatie speelt zich alweer in de wereld van de Freudiaanse symboliek af. Een interessant aspect van dit hoofdstuk is het plaatsen van het incestmotief in de joodse traditie. Aan bod komen thema's als ontheemding, het intussen zijn, verruiming van perspectief of ontwrichting van wetten. Incest wordt in deze context geïnterpreteerd als een symbolische zoektocht naar de oereenheid of naar huis, "symbool bij uitstek voor het menselijke verlangen naar een totale, mythische versmelting met de gelijke ander" (pg. 78). Ook in dit hoofdstuk refereert de auteur aan verschillende psychoanalytische concepten, zoals bijvoorbeeld het Lacaniaanse spiegelstadium of de symbolische orde.

Het laatste interpretatieve hoofdstuk wordt gewijd aan Alex van Warmerdams speelfilm Grimm, omschreven als "parodistische pastiche" (pg. 113) en een "postmoderne film waarin de hoofdpersonen op traditionele wijze blijk geven van verlangen of heimwee naar een 'thuis' dat ze niet kennen en nooit zullen vinden" (pg. 117). Ook in dit geval is de discussie vooral op een psychoanalytische aanpak gestoeld. De auteur wijst op verschillende genres die binnen deze film opgespoord kunnen worden, zoals het sprookje, de roadmovie, de thriller en de horror. Deze genres fungeren als ordeningsprincipe van het hoofdstuk. De discussie over de implicaties van de afzonderlijke genres is boeiend en vormt het sterkste element van dit hoofdstuk.

Het hoofdstuk wordt zo gestructureerd dat de plot van de film centraal staat, wat in de praktijk tot een samenvatting van de film leidt. Het thema van de incest tussen Jacob en zijn zus Marie is slechts één van meerdere kwesties waar de auteur haar aandacht aan besteedt. Volgens Coebergh-van der Marck is de film een pastiche van het genre van sprookje. Ze herkent er ook elementen van een queeste d.w.z. een zoektocht naar een cruciaal artefact. Verder bespreekt ze kort stereotypische representaties van de Spanjaarden en Nederlanders die in de film voorkomen. De zoektocht naar de warmte en passie die de traditioneel koude Nederlanders - in dit geval de hoofdpersonages Jacob 
en Marie - ondernemen, is er het meest sprekende voorbeeld van. Ze wijst ook op historische simplificaties: de Nederlandse opstand tegen de Spanjaarden en de "geuzenmentaliteit" worden beschouwd als een vorm van het subversieve denken (pg. 107). De voor een postmoderne film kenmerkende fenomenen van beeldcultuur en intertekstualiteit worden helaas niet uitvoeriger besproken.

Hoofdstuk 6 constitueert een samenvatting van de vier interpretatieve hoofdstukken en dus wordt er veel naverteld. De nadruk wordt geplaatst op de veranderingen en verschillen in de benadering tot het incestverbod: incest werd van oudsher beschouwd als overtreding van de goddelijke wet, maar is met de bovengenoemde culturele omslag gereduceerd tot aardse proporties. Daarnaast biedt het postmoderne denken talrijke interpretatieve alternatieven voor het verschijnsel van incest. Met andere woorden, de gekozen werken dienen als illustraties van verschillende artistieke toepassingen van het incestmotief.

De breed geschetste theoretische achtergrond getuigt van een grote eruditie van de auteur en van een goed, grondig onderzoek van het probleem; zo wordt er bijvoorbeeld verwezen naar werken die in meerdere talen en in verschillende tijdperken geschreven zijn. Het boek heeft helaas een paar zwakke punten. Ten eerste belooft de auteur in de inleiding dat ze zich op de historische en maatschappelijke context van de werken zal concentreren. Wat ze in werkelijkheid presenteert is niet zozeer een historisch overzicht, maar meer een chronologisch overzicht van de mentale veranderingen in het wereldbeeld en beoordelingen van incest. Het lijkt erop dat de psychoanalytische theorie andere aspecten van cultuur en geschiedenis domineert, zodat andere benaderingen en problemen alleen de rol van kanttekeningen vervullen. Wat ontbreekt is een duidelijk gepresenteerde historische context, namelijk het situeren van de omslag in het beschouwen van incest tegen een achtergrond van historische veranderingen: welke gebeurtenissen in de globale en Nederlandse context hebben bijgedragen tot deze ommekeer in de wereldbeschouwing? Als de auteur over de postkoloniale maatschappij schrijft (Mijn zuster de negerin), legt ze niet uit wat voor deze maatschappij karakteristiek is en met welke problemen die moet kampen. Verder is er in Het satijnen hart sprake van het naoorlogse trauma, maar de link tussen het trauma en incest wordt niet expliciet toegelicht. Daarnaast ontstaat er soms de indruk dat aanhalingen uit de primaire werken alleen als voorwendsel dienen voor een uitgebreide theoretische passage. Kortom, het boek zou toegankelijker zijn als in plaats van uitvoerige theoretische en, in feite, abstracte overwegingen, de auteur de inhoud van de besproken boeken beter in een historische achtergrond had verankerd.

Ten tweede is het eigenlijk moeilijk om de doelgroep van dit boek te bepalen, want de auteur lijkt niet consequent te zijn. Aan de ene kant bevat de tekst tamelijk veel aanhalingen uit werken van verschillende theoretici en deze citaten (dikwijls in het Duits, Frans of Engels) worden niet vertaald. De auteur lijkt erop te rekenen dat haar geïmpliceerde lezer al deze talen machtig is. Maar aan de andere kant legt de auteur sommige begrippen uit die voor een goed belezen polyglot duidelijk zouden moeten zijn. Het verklaren van de herkomst van het concept "narcisme" (pg. 57) of betekenissen van "sublimering" (pg. 48), "polyvalentie" en "polysemie" (pg. 31) is voor een dergelijke erudiete lezer overbodig. 
Concluderend kan er zeker gezegd worden dat het boek een goed inzicht in de problematiek van incest in literatuur en cultuur biedt. De uitleg over de culturele en literaire betekenis van het incestmotief is in de geselecteerde werken ondersteund door talrijke citaten en verwijzingen naar theorie. De focus op psychoanalyse zal echter niet iedere lezer aanspreken.

Małgorzata Drwal

Uniwersytet im. Adama Mickiewicza mdrwal@wa.amu.edu.pl 